\title{
Integrated Status and Effectiveness Monitoring Program \\ -Entiat River Snorkel Surveys, 2006-2007.
}

July 2006- June 2007

\author{
Prepared by: \\ R.D. Nelle \\ Fishery Biologist \\ U.S. Fish and Wildlife Service \\ Mid-Columbia River Fishery Resource Office \\ 7501 Icicle Rd. \\ Leavenworth WA 98826
}

Funded by

U.S. Department of Energy

Bonneville Power Administration

Division of Fish and Wildlife

Portland, OR. 97208-3621

Project No. 2003-017-00

Contract No. 28029

October, 2007 


\section{Table of Contents}

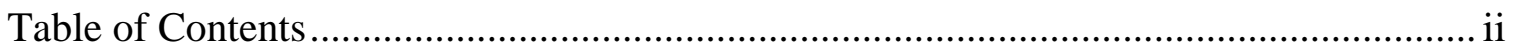

List of Tables ........................................................................................................ ii

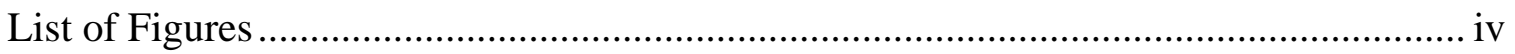

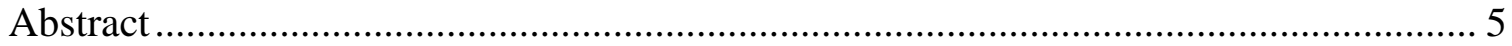

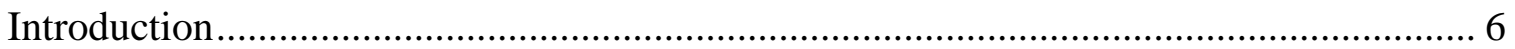

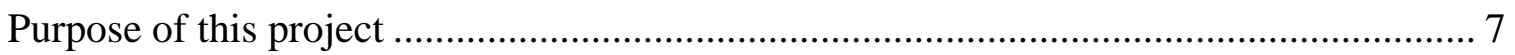

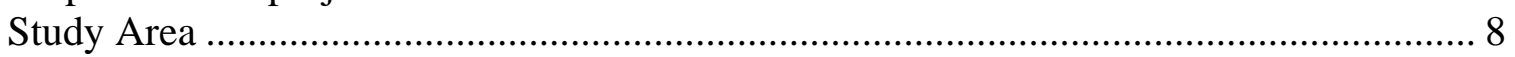

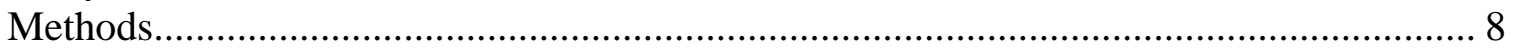

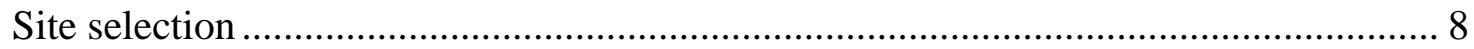

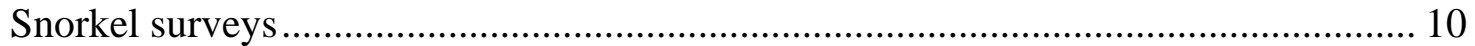

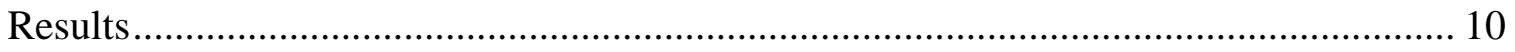

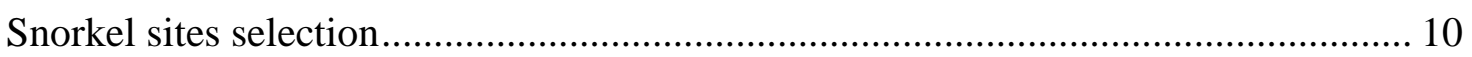

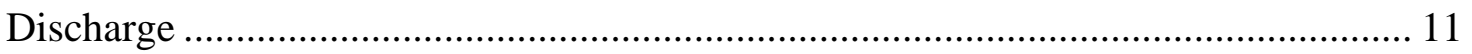

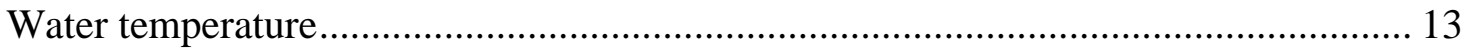

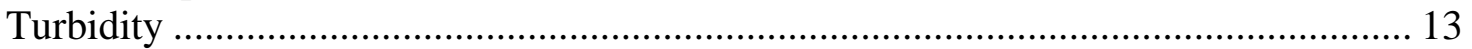

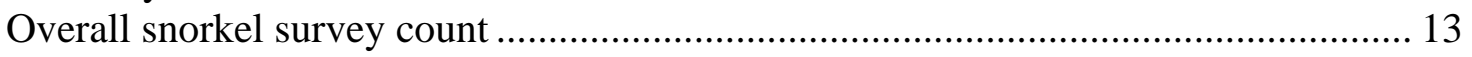

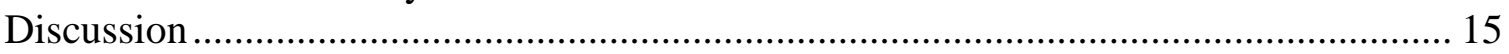

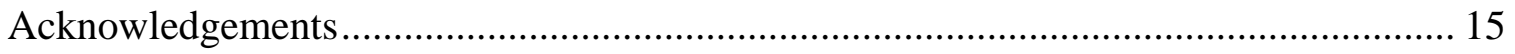

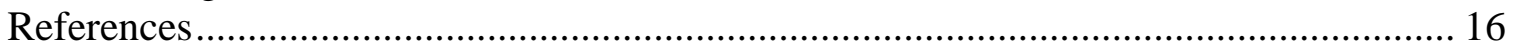

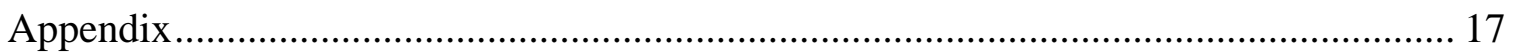




\section{List of Tables}

Table 1 Experimental site descriptions and locations snorkeled in the Entiat River during the period from August 2006 to March 2007.

Table 2 Water quality measurements for sites and times snorkeled in the Entiat River during 2006 to 2007. Mean discharge data is from USGS gage site number 12452990.

Table 3 The number of fish species observed by period and time of day during snorkel surveys in the Entiat River during 2006-2007................................................... 14 


\section{List of Figures}

Figure 1. Study reach map of the Entiat River watershed and study reach from Rkm 0.5

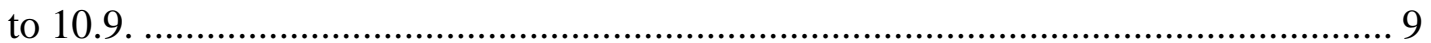

Figure 2. Daily mean discharge $\left(\mathrm{ft}^{3} / \mathrm{sec}\right)$ for the period from July 1, 2006 to June 30, 2007 for USGS gage station 12452990 at Rkm 2.3 in the Entiat River. 13 


\begin{abstract}
The USFWS Mid-Columbia River Fishery Resource Office conducted snorkel surveys at 11 sites during the summer 2006 survey period and at 15 sites during fall 2006 and winter 2007 survey periods as part of the Integrated Status and Effectiveness Monitoring Program in the Entiat River. A total of 39,898 fish from 14 species/genera and an unknown category were enumerated. Chinook salmon were the overall most common fish observed and comprised 19\% of fish enumerated followed by mountain whitefish (18\%) and rainbow trout (14\%). Day and night surveys were conducted during the summer 2006 period (August), while night surveys were conducted during the fall 2006 (October) and winter 2007 (February/March) surveys.
\end{abstract}




\section{Introduction}

The Integrated Status and Effectiveness Monitoring Program (ISEMP - BPA project \#2003-0017) has been created as a cost effective means of developing protocols and new technologies, novel indicators, sample designs, analytical, data management and communication tools and skills, and restoration experiments that support the development of a region-wide Research, Monitoring and Evaluation (RME) program to assess the status of anadromous salmonid populations, their tributary habitat and restoration and management actions.

The most straightforward approach to developing a regional-scale monitoring and evaluation program would be to increase standardization among status and trend monitoring programs. However, the diversity of species and their habitat, as well as the overwhelming uncertainty surrounding indicators, metrics, and data interpretation methods, requires the testing of multiple approaches. Thus, the approach ISEMP has adopted is to develop a broad template that may differ in the details among subbasins, but one that will ultimately lead to the formation of a unified RME process for the management of anadromous salmonid populations and habitat across the Columbia River Basin.

ISEMP has been initiated in three pilot subbasins, the Wenatchee/Entiat, John Day, and Salmon. To balance replicating experimental approaches with the goal of developing monitoring and evaluation tools that apply as broadly as possible across the Pacific Northwest, these subbasins were chosen as representative of a wide range of potential challenges and conditions, e.g., differing fish species composition and life histories, ecoregions, institutional settings, and existing data.

ISEMP has constructed a framework that builds on current status and trend monitoring infrastructures in these pilot subbasins, but challenges current programs by testing alternative monitoring approaches. In addition, the ISEMP is:

1) Collecting information over a hierarchy of spatial scales, allowing for a greater flexibility of data aggregation for multi-scale recovery planning assessments, and

2) Designing methods that:

a) Identify factors limiting fish production in watersheds;

b) Determine restoration actions to address these problems;

c) Implement actions as a large-scale experiment (e.g. Before After Control Impact, or BACI design), and

d) Implement intensive monitoring and research to evaluate the action's success.

The intent of the ISEMP project is to design monitoring programs that can efficiently collect information to address multiple management objectives over a broad range of scales. This includes:

- Evaluating the status of anadromous salmonids and their habitat;

- Identifying opportunities to restore habitat function and fish performance, and 
- Evaluating the benefits of the actions to the fish populations across the Columbia River Basin.

The multi-scale nature of this goal requires the standardization of protocols and sampling designs that are statistically valid and powerful, properties that are currently inconsistent across the multiple monitoring programs in the region. Other aspects of the program will aid in the ability to extrapolate information beyond the study area, such as research to elucidate causal mechanisms, and a classification of watersheds throughout the Columbia River Basin. Obviously, the scale of the problem is immense and the ISEMP does not claim to be the only program working towards this goal. As such, ISEMP relies heavily on the basin's current monitoring infrastructure to test and develop monitoring strategies, while acting as a coordinating body and providing support for key elements such as data management and technical analyses. The ISEMP also ensures that monitoring programs can address large-scale management objectives (resulting largely from the ESA) through these local efforts. While the ISEMP maintains a regional focus it also returns the necessary information to aid in management at the smaller spatial scales (individual projects) where manipulations (e.g., habitat restoration actions) actually occur.

The work captured in this report is a component of the overall Integrated Status and Effectiveness Monitoring Program, and while it stands alone as an important contribution to the management of anadromous salmonids and their habitat, it also plays a key role within ISEMP. Each component of work within ISEMP is reported on individually, as is done so here, and in annual and triennial summary reports that present all of the overall project components in their programmatic context and shows how the data and tools developed can be applied to the development of regionally consistent, efficient and effective Research, Monitoring and Evaluation.

\section{Purpose of this project}

This is second annual progress report to Bonneville Power Administration for the snorkel surveys conducted in the Entiat River as related to long-term effectiveness monitoring of restoration programs in this watershed.

In 2005, the Cascadia Conservation District (CCD) in association with the Entiat Watershed Planning Unit (EWPU) initiated a large-scale restoration program in a $2000 \mathrm{~m}$ section of the Entiat River watershed, known as the "Entiat Bridge-to-Bridge Project". This is a phased program that will, over a several year period, incorporate a suite of stream restoration measures that include in-stream habitat structures, the reconnection of relict stream channels, and riparian plantings. This project has since grown to include the Entiat River downstream of the Entiat National Fish Hatchery at Rkm 10.9. The restoration efforts in the Entiat River are intended to provide complexity to the river system and a positive benefit for aquatic organisms including ESA listed fish species.

The Entiat River Effectiveness Monitoring Study plans to evaluate fish utilization of instream habitat modifications within the Entiat River. The U.S. Fish and Wildlife Service's Mid-Columbia River Fishery Resource Office (MCRFRO) is conducting the snorkeling component of the Entiat Effectiveness Monitoring Study that will evaluate fish habitat utilization associated with in-stream restoration work planned for the lower Entiat River. 
The objective of this study is to monitor the fish habitat utilization of planned in-stream restoration efforts in the Entiat River by conducting pre- and post-construction snorkel surveys at selected treatment and control sites.

\section{Study Area}

The Entiat River watershed originates from 11 glaciers and snowfields in the Cascade Mountains and flows southeast approximately $69 \mathrm{~km}$ to join the Columbia River at river kilometer (Rkm) 778 (CCCD 2004, Mullan et al. 1992). The Entiat watershed is bordered by the Entiat Mountains to the southwest and the Chelan Mountains to the northeast and drains approximately $1,085 \mathrm{~km}^{2}$. The topography is steep with unstable erodible soils and vegetation types varying from semi-arid shrub steppe near the confluence with the Columbia River to temperate forests and alpine meadows in the headwaters.

Past glacial activity has shaped the Entiat River valley by creating a U-shaped valley upstream of terminal moraine at Rkm 26.1 and V shaped valley downstream (Mullan et al. 1992). The present upstream limit to anadromy is at Entiat Falls Rkm 54.4.

The study reach is located in lower Entiat River between the Rkm 0.5 to 10.9 ( $\mathrm{Rm} 0.3$ to 6.8) and the Bridge to Bridge section is located between Rkm 5.2 to 7.4 ( $R m 3.2$ to 4.6) Figure 1).

The Entiat River watershed supports seven native and one introduced salmonid species which include, spring and summer Chinook salmon Oncorhynchus tshawytscha, steelhead and resident rainbow trout $O$. mykiss gairdneri, sockeye salmon $O$. nerka, westslope cutthroat trout $O$. clarki lewisi, coho salmon O. kisutch, mountain whitefish Prosopium williamsoni, bull trout Salvelinus confluentus, and introduced eastern brook trout $S$. fontinalis. Other fish species include, chiselmouth Acrocheilus alutaceus, northern pikeminnow Ptychocheilus oregonensis, largescale sucker Catostomus macrocheilus, bridgelip sucker $C$. columbianus, speckled dace Rhinichthys osculus, longnose dace $R$. cataractae, redside shiner Richardsonius balteatus, sculpin Cottus spp., three-spined stickleback Gasterosteus aculeatus and Pacific lamprey Entosphenus tridentatus. (Mullan et al 1992, CCCD 2004, Wydoski and Whitney 2003).

\section{Methods}

Fish were surveyed by direct observation using single-pass snorkeling as described by Thurow (1994) at 11 sample sites during the summer of 2006 and 15 sampling sites during fall 2006 and winter 2007.

\section{Site selection}

Snorkel sites locations were identified jointly by USFWS and Terraqua, Inc. Site locations were defined by using locations of proposed habitat structures (treatment sites), locations of existing habitat structures (existing control sites), and information from Rosgen stream typing classification methods to select sites with a similar channel types as treatment sites for sites not subject to modifications (control sites). 


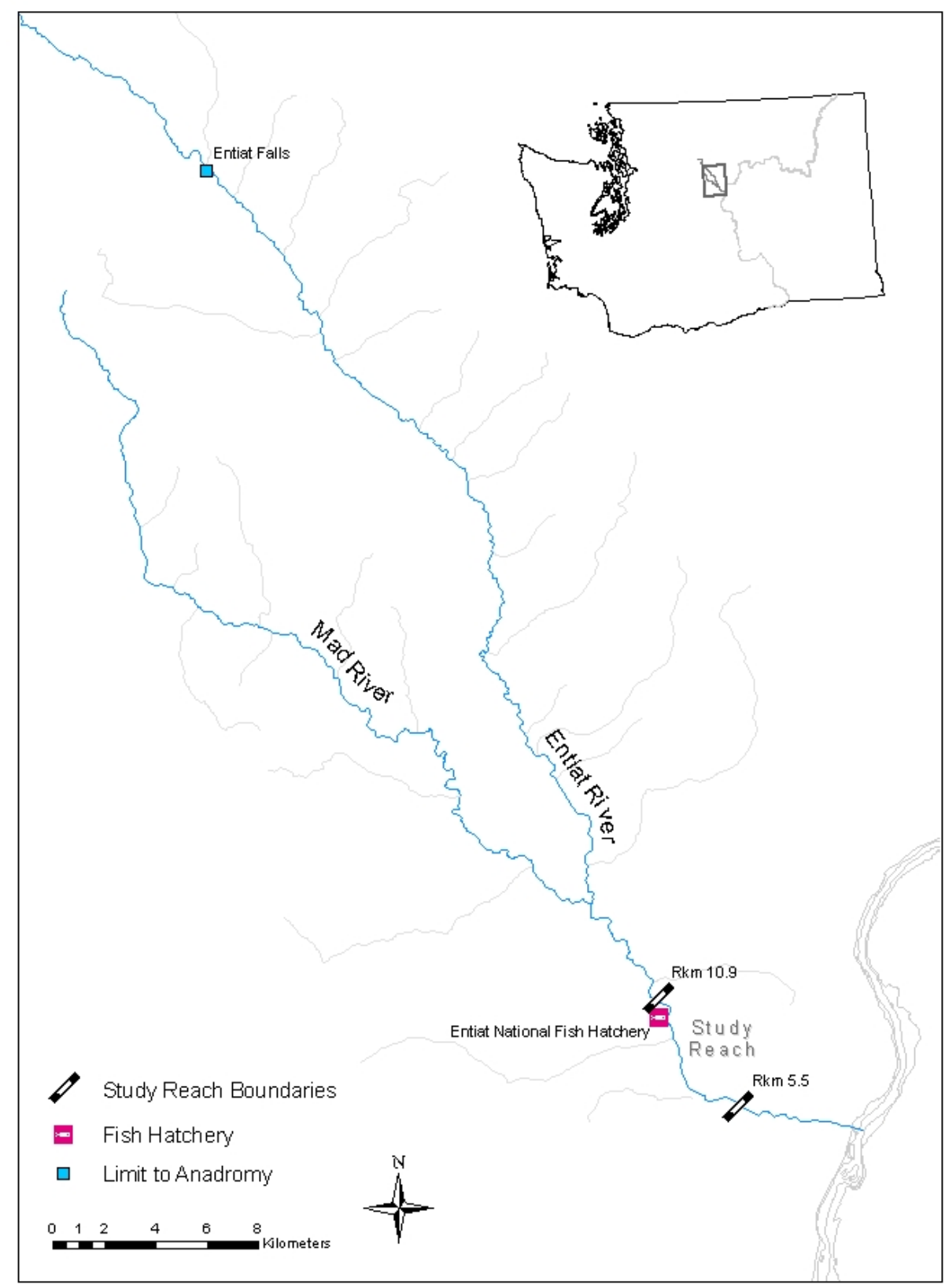

Figure 1. Study reach map of the Entiat River watershed and study reach from Rkm 0.5 to 10.9 . 
Treatment and existing control sites were setup to place the area surveyed in the middle of the section to be modified or presently modified. All control sites and existing control sites were selected upstream of the treatment section. Snorkel sites were defined to be $200 \mathrm{~m}$ in length in the main river sites and $240 \mathrm{~m}$ or less in off-channel sites. Each site was further divided into habitat units, monumented, and flagged.

Snorkel surveys

Snorkel surveys were conducted at three time periods throughout the year: the summer period (July/August after peak discharge), the fall period (mid-October/November), and the winter period (February/March). During each survey period, snorkeling was conducted at night; however during the summer survey period an additional daytime snorkel was conducted at each site.

Night snorkeling commenced no earlier than 30 minutes past the official sunset at Entiat, WA, or after the first star or planet was observed in the sky. Prior to night snorkeling, glow sticks were affixed at habitat unit breaks to assist crews in defining the sample site.

Up to nine snorkelers and at least one shore tender were used to conduct the snorkel surveys in the mainstem river snorkel sites. Off channel sites were snorkeled by one to four snorkelers depending on the site width. Snorkel crews entered the snorkel site downstream of the site and snorkeled as unit in an upstream direction to the end of that site. Snorkelers were positioned across the stream channel so as to cover the entire channel bank to bank. Shore tenders estimated fish numbers in the water too shallow to snorkel. Snorkelers used dry suits, wet or dry gloves, felt bottom wading boots, a mask and a snorkel. Hand-held dive lights were used at night to illuminate the survey area. Data was recorded by each snorkeler on a PVC cuff secured to their arm and data were transferred to a datasheet at the end of each habitat units. Fish count data from snorkelers was recorded on datasheets by fish size and snorkel lanes looking upstream left to right. Water temperature was collected at the start and end of each site. Turbidity water samples were collected once during the snorkel survey and processed following the snorkel survey. All fish observed were counted by species and assigned to a $20 \mathrm{~mm}$ size class within each habitat unit.

In the office, data were transferred to a database and proofed for concurrence with field datasheets.

\section{Snorkel sites selection}

\section{Results}

A total of 11 previous sample sites and four new sample sites were snorkeled during the August 2006 to March 2007 period. Sites included five planned main-river treatment site and one adjacent off-channel habitat site. Four pre-existing treatment sites were sampled which included three main-river and one adjacent off-channel site. Five control sites were selected which included three main river and two adjacent off-channel sites (Table 1). 
Table 1. Experimental site descriptions and locations snorkeled in the Entiat River during the period from August 2006 to March 2007.

\begin{tabular}{lcccccc}
\hline \multicolumn{1}{c}{ Site name } & $\begin{array}{c}\text { Experimental } \\
\text { site type }\end{array}$ & $\begin{array}{c}\text { Channel } \\
\text { location }\end{array}$ & $\begin{array}{c}\text { River } \\
\text { kilometer } \\
\text { (km) }\end{array}$ & $\begin{array}{c}\text { Site } \\
\text { length } \\
\text { (m) }\end{array}$ & $\begin{array}{c}\text { Mid-point } \\
\text { Lat (N) }\end{array}$ & Long (W) \\
\hline City limits main & Treatment & Main & 0.5 & 200 & 47.66320 & 120.23643 \\
City limits side channel & Treatment & Off & 0.5 & 200 & 47.66320 & 120.23643 \\
Keystone Canyon & Treatment & Main & 3.7 & 200 & 47.66528 & 120.26584 \\
Milne & Treatment & Main & 4.3 & 200 & 47.66546 & 120.27232 \\
Whitehall cross vane & Treatment & Main & 5.5 & 200 & 47.66920 & 120.28440 \\
PUD canal & Treatment & Off & 5.5 & 240 & 47.66860 & 120.28298 \\
Dinkelman cross vane & Existing treatment & Main & 7.4 & 200 & 47.67207 & 120.30595 \\
Stanton-Love & Control & Main & 8.4 & 200 & 47.67761 & 120.31252 \\
Hanan-Detwiler ditch & Control & Off & 8.4 & 200 & 47.67616 & 120.31201 \\
Jon Small barbs & Existing treatment & Main & 8.8 & 200 & 47.68088 & 120.31263 \\
Knapp-Wham main & Control & Main & 9.3 & 200 & 47.68556 & 120.31562 \\
Knapp-Wham ditch & Control & Off & 9.3 & 100 & 47.68609 & 120.31564 \\
Wilson main & Existing treatment & Main & 10.6 & 200 & 47.69548 & 120.32093 \\
Wilson side channel & Existing treatment & Off & 10.6 & 200 & 47.69606 & 120.32128 \\
Hatchery & Control & Main & 10.9 & 200 & 47.69869 & 120.32396 \\
\hline
\end{tabular}

\section{Discharge}

Daily mean discharge for all sites and periods ranged from a low of $95 \mathrm{ft}^{3} / \mathrm{sec}$ during the fall 2006 snorkel to a high of $258 \mathrm{ft}^{3} /$ sec during winter 2007 snorkel (Table 2). Daily mean discharge within a sample period varied from $1 \mathrm{ft}^{3} / \mathrm{sec}$ during the fall 2006 period to $27 \mathrm{ft}^{3} / \mathrm{sec}$ during the winter 2007 period. Snorkel surveys were conducted during low water periods of the year, which is reflected in the yearly hydrograph (Figure 2). The two summer 2006 snorkel surveys were conducted during a period of descending discharge. The fall 2006 snorkel survey was conducted during a low stable period of discharge. The winter 2007 snorkel was conducted during a slightly decreasing discharge period before the spring run off.

Table 2. Water quality measurements for sites and times snorkeled in the Entiat River during 2006 to 2007. Mean discharge data is from USGS gage site number 12452990.

\begin{tabular}{|c|c|c|c|c|c|c|}
\hline $\begin{array}{l}\text { Survey period- } \\
\text { Snorkel time }\end{array}$ & Site name & $\begin{array}{c}\text { River } \\
\text { kilometer } \\
(\mathbf{k m})\end{array}$ & $\begin{array}{c}\text { Snorkel } \\
\text { date }\end{array}$ & $\begin{array}{c}\text { Discharge } \\
\left(\mathrm{ft}^{3} / \mathrm{sec}\right)\end{array}$ & $\begin{array}{c}\text { Temperature } \\
{ }^{\circ} \mathrm{C}\end{array}$ & $\begin{array}{c}\text { Turbidity } \\
\text { NTU }\end{array}$ \\
\hline \multirow[t]{11}{*}{$\begin{array}{l}\text { Summer-night } \\
\text { Sum }\end{array}$} & Whitehall cross vane & 5.5 & 08/10/06 & 198 & 17.7 & 1.0 \\
\hline & PUD canal & 5.5 & 08/10/06 & 198 & 17.0 & 1.0 \\
\hline & Dinkelman cross vane & 7.4 & 08/09/06 & 199 & 16.5 & 1.3 \\
\hline & Stanton-Love & 8.4 & 08/08/06 & 203 & 17.5 & 0.7 \\
\hline & Hanan-Detwiler ditch & 8.4 & 08/06/06 & 217 & 18.9 & 1.2 \\
\hline & Jon Small barbs & 8.8 & 08/09/06 & 199 & 19.0 & 0.7 \\
\hline & Knapp-Wham main & 9.3 & 08/10/06 & 198 & 18.5 & 1.4 \\
\hline & Knapp-Wham ditch & 9.3 & $08 / 11 / 06$ & 193 & 16.0 & 1.4 \\
\hline & Wilson main & 10.6 & 08/07/06 & 208 & 18.9 & 0.6 \\
\hline & Wilson side channel & 10.6 & 08/06/06 & 217 & 17.6 & 1.3 \\
\hline & Hatchery & 10.9 & 08/08/06 & 203 & 18.2 & 0.6 \\
\hline
\end{tabular}


Table 2. Water quality measurements for sites and times snorkeled in the Entiat River from 2006 to 2007. Mean discharge data is from USGS gage site number 12452990, continued.

\begin{tabular}{|c|c|c|c|c|c|c|}
\hline $\begin{array}{l}\text { Survey period- } \\
\text { Snorkel time }\end{array}$ & Site name & $\begin{array}{c}\text { River } \\
\text { kilometer } \\
(\mathbf{k m})\end{array}$ & $\begin{array}{c}\text { Snorkel } \\
\text { date } \\
\end{array}$ & $\begin{array}{c}\text { Discharge } \\
\left(\mathrm{ft}^{3} / \mathrm{sec}\right) \\
\end{array}$ & $\begin{array}{c}\text { Temperature } \\
{ }^{\circ} \mathrm{C} \\
\end{array}$ & $\begin{array}{c}\text { Turbidity } \\
\text { NTU } \\
\end{array}$ \\
\hline \multirow[t]{11}{*}{ Summer-day } & Whitehall cross vane & 5.5 & 08/18/06 & 158 & 16.3 & 0.6 \\
\hline & PUD canal & 5.5 & 08/18/06 & 158 & 17.2 & 0.6 \\
\hline & Dinkelman cross vane & 7.4 & 08/17/06 & 165 & 18.6 & 0.6 \\
\hline & Stanton-Love & 8.4 & 08/17/06 & 165 & 17.0 & 0.5 \\
\hline & Hanan-Detwiler ditch & 8.4 & 08/16/06 & 167 & 16.9 & 0.5 \\
\hline & Jon Small barbs & 8.8 & 08/14/06 & 175 & 18.3 & 0.8 \\
\hline & Knapp-Wham main & 9.3 & 08/14/06 & 175 & 15.8 & 0.8 \\
\hline & Knapp-Wham ditch & 9.3 & 08/18/06 & 158 & 17.6 & NA \\
\hline & Wilson main & 10.6 & 08/15/06 & 169 & 20.4 & 0.6 \\
\hline & Wilson side channel & 10.6 & 08/16/06 & 167 & 18.3 & 0.8 \\
\hline & Hatchery & 10.9 & 08/15/06 & 169 & 18.2 & 0.7 \\
\hline \multirow[t]{15}{*}{ Fall-night } & City limits main & 0.5 & 10/30/06 & 96 & 2.0 & 0.6 \\
\hline & City limits side channel & 0.5 & 10/30/06 & 96 & 2.7 & 0.6 \\
\hline & Keystone Canyon & 3.7 & 10/26/06 & 95 & 8.6 & 0.8 \\
\hline & Milne & 4.3 & 10/30/06 & 96 & 3.8 & 0.6 \\
\hline & Whitehall cross vane & 5.5 & 10/26/06 & 95 & 8.1 & 0.9 \\
\hline & PUD canal & 5.5 & 10/26/06 & 95 & 8.0 & 1.6 \\
\hline & Dinkelman cross vane & 7.4 & $10 / 24 / 06$ & 96 & 7.1 & 0.6 \\
\hline & Stanton-Love & 8.4 & 10/23/06 & 96 & 7.5 & 0.7 \\
\hline & Hanan-Detwiler ditch & 8.4 & $10 / 22 / 06$ & 96 & 6.8 & 0.8 \\
\hline & Jon Small barbs & 8.8 & $10 / 25 / 06$ & 96 & 7.2 & 0.5 \\
\hline & Knapp-Wham main & 9.3 & 10/24/06 & 96 & 6.7 & 0.6 \\
\hline & Knapp-Wham ditch & 9.3 & $10 / 24 / 06$ & 96 & 6.8 & 0.6 \\
\hline & Wilson main & 10.6 & 10/23/06 & 96 & 7.2 & 0.5 \\
\hline & Wilson side channel & 10.6 & 10/22/06 & 96 & 7.0 & 0.5 \\
\hline & Hatchery & 10.9 & $10 / 25 / 06$ & 96 & 6.7 & 0.5 \\
\hline \multirow[t]{15}{*}{ Winter-night } & City limits main & 0.5 & 02/28/07 & 242 & 3.0 & NA \\
\hline & City limits side channel & 0.5 & 02/28/07 & 242 & 3.0 & NA \\
\hline & Keystone Canyon & 3.7 & 02/25/07 & 258 & 3.4 & 1.1 \\
\hline & Milne & 4.3 & 02/26/07 & 251 & 3.4 & 1.5 \\
\hline & Whitehall cross vane & 5.5 & 02/26/07 & 251 & 3.9 & 1.0 \\
\hline & PUD canal & 5.5 & 02/26/07 & 251 & 4.3 & 1.0 \\
\hline & Dinkelman cross vane & 7.4 & 02/27/07 & 245 & 3.8 & 0.8 \\
\hline & Stanton-Love & 8.4 & $02 / 27 / 07$ & 245 & 3.1 & 1.0 \\
\hline & Hanan-Detwiler ditch & 8.4 & 02/27/07 & 245 & 2.6 & 1.0 \\
\hline & Jon Small barbs & 8.8 & 03/01/07 & 231 & 3.1 & 0.7 \\
\hline & Knapp-Wham main & 9.3 & 02/28/07 & 242 & 2.8 & 0.8 \\
\hline & Knapp-Wham ditch & 9.3 & $02 / 28 / 07$ & 242 & 2.6 & 0.8 \\
\hline & Wilson main & 10.6 & 03/01/07 & 231 & 1.8 & 0.7 \\
\hline & Wilson side channel & 10.6 & 03/01/07 & 231 & 1.5 & 0.8 \\
\hline & Hatchery & 10.9 & 02/25/07 & 258 & 2.7 & 1.3 \\
\hline
\end{tabular}




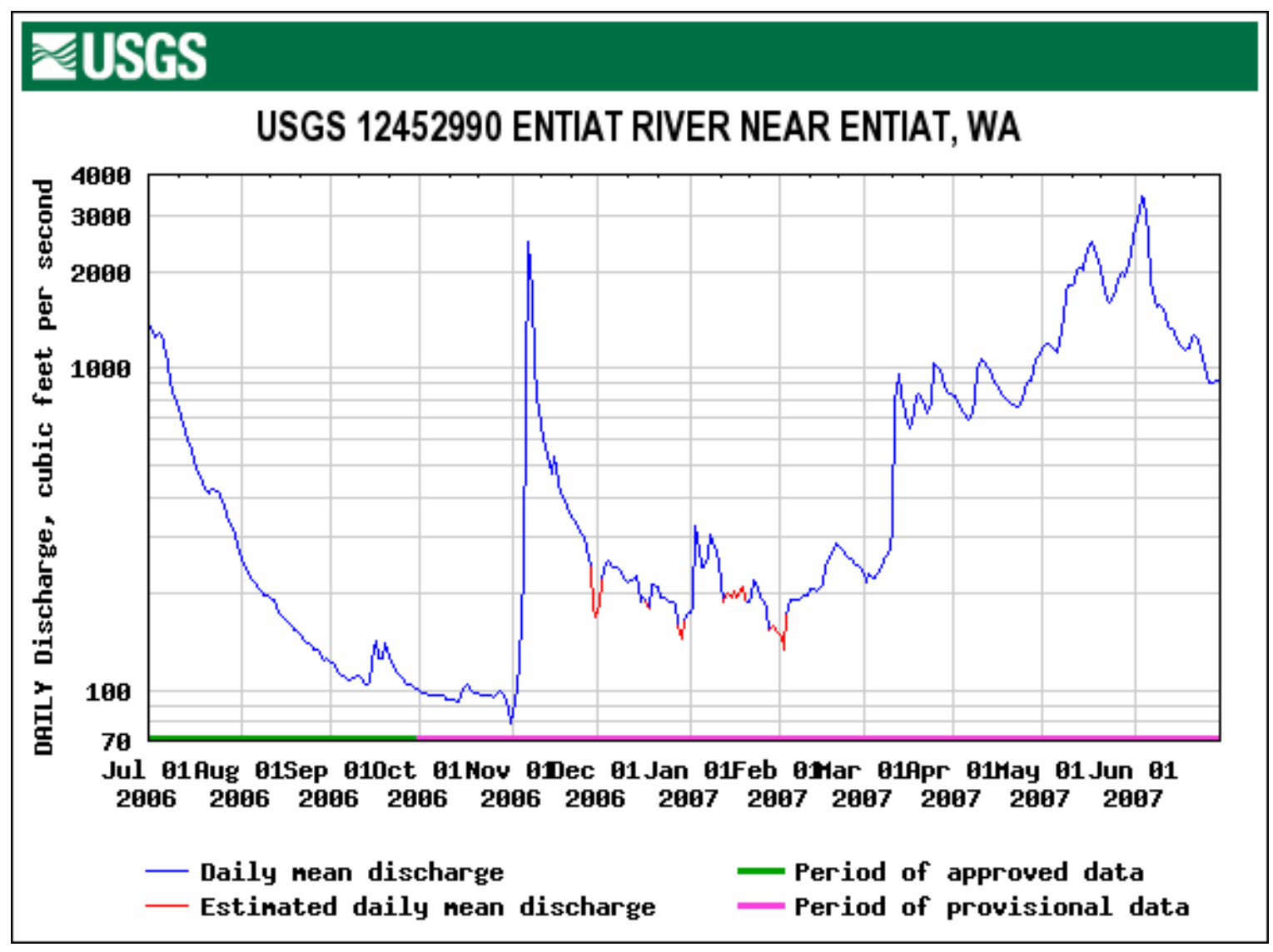

Figure 2. Daily mean discharge ( $\left.\mathrm{ft}^{3} / \mathrm{sec}\right)$ for the period from July 1, 2006 to June 30, 2007 for USGS gage station 12452990 at Rkm 2.3 in the Entiat River.

\section{Water temperature}

Water temperatures were relatively consistent within a period expect during the fall 2006 period when water temperature decreased by $6.6{ }^{\circ} \mathrm{C}$ during the last part of the sample period (Table 2). The summer night and day 2006 periods had mean water temperature of $17.8^{\circ} \mathrm{C}$ (SD 1.00) and $17.7^{\circ} \mathrm{C}$ (SD 1.26 ), respectively. During the fall period 2006, mean water temperatures was $6.4{ }^{\circ} \mathrm{C}$ (SD 1.97). During the winter 2007 period mean water temperature was $3.0^{\circ} \mathrm{C}(\mathrm{SD} 0.74)$.

\section{Turbidity}

Mean water turbidity by period was $\leq 1.0$ NTU (Table 2). The lowest turbidity levels were recorded during the summer-day 2006 and fall 2006 snorkel periods and the highest mean turbidity levels were recorded during the summer-night 2006 and winter 2007 periods.

Overall snorkel survey count

All snorkel sites were successfully snorkeled during planned periods and times of day. A total of 39,898 fish were counted from all time periods and sites during the period form 2006 to 2007 (Table 3). The greatest number of fish observed was during the summer- 
day 2006 period with 44\% of the overall total, followed by summer-night 2006 (38\%), fall-night 2006 (15\%), and winter-night 2007 (3\%). The number of fish observed during day and night snorkel surveys by site surveyed in the Entiat River during 2006 to 2007 can be found in Appendix table 1.

Table 3. The number of fish species observed by period and time of day during snorkel surveys in the Entiat River during 2006-2007.

\begin{tabular}{lccccc}
\hline \multicolumn{1}{c}{ Fish } & $\begin{array}{c}\text { Summer } \\
\text { Say }\end{array}$ & $\begin{array}{c}\text { Summer } \\
\text { night }\end{array}$ & $\begin{array}{c}\text { Fall } \\
\text { night }\end{array}$ & $\begin{array}{c}\text { Winter } \\
\text { night }\end{array}$ & Total \\
\hline Bull trout & 5 & 7 & 10 & 1 & 23 \\
Chinook salmon & 2,481 & 2,864 & 2,038 & 205 & 7,588 \\
Chiselmouth & 1 & 1 & 0 & 0 & 2 \\
Cutthroat trout & 2 & 0 & 1 & 0 & 3 \\
Dace spp. & 58 & 898 & 234 & 11 & 1,201 \\
Lamprey spp. & & 7 & 1 & 5 & 13 \\
Mountain whitefish & 3,347 & 3,493 & 201 & 51 & 7,092 \\
Pikeminnow & 1 & 5 & 0 & 0 & 6 \\
Rainbow trout & 1,674 & 1,449 & 1,530 & 736 & 5,389 \\
Redside shiner & 1 & 0 & 137 & 1 & 139 \\
Sculpin spp. & 10 & 12 & 32 & 12 & 66 \\
Sockeye salmon & 0 & 0 & 1 & 0 & 1 \\
Stickleback & 0 & 0 & 1,243 & 0 & 1,243 \\
Sucker spp. & 110 & 112 & 254 & 9 & 485 \\
Unknown fish & 10,019 & 6,341 & 283 & 4 & 16,647 \\
Grand Total & 17,709 & 15,189 & 5,965 & 1,035 & 39,898 \\
\hline
\end{tabular}

For fish identified to species or genera, Chinook salmon comprised 19\% of the total fish observed followed by mountain whitefish (18\%), rainbow trout (14\%), dace spp. (3\%), and stickleback (3\%). Unidentified species/genera fish comprised $42 \%$ of the observed fish and were primarily juvenile or larval fish observed in water too shallow to snorkel along the river margins. The remaining percentage of fish identified to species/genera $(<2 \%)$ were comprised of bull trout, chiselmouth, cutthroat trout, lamprey spp., northern pikeminnow, redside shiner, sculpin spp., sockeye salmon, and sucker spp..

For seasonal time periods and time of day snorkeled, mountain whitefish were observed in the greatest numbers in the summer 2006 day and night surveys followed by Chinook salmon and rainbow trout. Chinook salmon were the most common during the fall 2006 night survey followed by rainbow trout. The number of unknown fish counted decreased during the fall 2006 and winter 2007 surveys compared to summer 2006 surveys.

The total numbers of Chinook salmon, dace spp., mountain whitefish, sculpin spp. observed increased during summer-night 2006 surveys compared to the summer-day 2006 surveys, while the number of rainbow trout decreased during the summer-night 2006 snorkel. 


\section{Discussion}

Snorkel surveys conducted by the MCRFRO in the Entiat River from August 2006 to March 2007 as part of the Integrated Status and Effectiveness Monitoring Program in the Entiat River were conducted on time and within the planned sample periods. These snorkel surveys were conducted under decreasing or low flows and low turbidity conditions creating ideal snorkeling conditions.

During the winter 2007surveys, daily mean discharge readings exceeded 250 cfs., thus providing the highest discharge to date under which USFWS has conducted snorkel surveys in the main Entiat River. These higher flows during the winter 2007 snorkel surveys allowed us to better define the discharge at the Entiat gage in which snorkel surveys can effectively and safely be conducted in the Entiat River downstream of the Mad River. From USFWS snorkelers' observations, a discharge between 250 to 275 cfs is judged to be the maximum discharge that most sites in the lower Entiat River can be effectively and safely snorkeled using these methods.

Starting with the fall 2006 survey period, four new treatment sites were added to the snorkeling schedule: City limits main (Rkm 0.5), City limits side channel (Rkm 0.5), Keystone Canyon (Rkm 3.7), and Milne (Rkm 4.3). During the fall 2006 snorkel period at the Milne site, snorkelers surveyed an additional 19.5 meters of river upstream not in the habitat site. The fish counts for habitat unit 3 were inflated by the additional 19.5 meters snorkeled and this will need to be taken into account for future analysis.

During this period of the project two snorkel treatment sites were modified using restoration methods. The cross vane structure at the Whitehall site was installed and the adjacent upper section of the PUD canal was modified with the addition of large wood debris, boulders, and pools. The construction occurred between the summer and fall 2006 snorkel surveys. The creation of a large pool, disturbed gravel substrate and pool tail out at the Whitehall site provided habitat for spawning summer Chinook salmon which congregated in large number at that site during the fall 2006 survey.

A MCRFRO effectiveness monitoring snorkel protocol was updated to describe the methods in detail.

Project goals were met during the 2006 to 2007 field season. Continued snorkel surveys will be needed to evaluate the before and after restoration efforts and meet the long-term effectiveness monitoring program goals in the Entiat River.

\section{Acknowledgements}

Many thanks go to the core group of MCRFRO snorkelers. Additional thanks goes to the snorkeling support from Leavenworth National Fish Hatchery and support and shelter provided by Entiat National Fish Hatchery. 


\section{References}

Chelan County Conservation District. 2004. Entiat Water Resource Inventory (WRIA) 46 Management Plan. October 2004. Prepared for the Entiat Watershed Planning Unit by the Chelan County Conservation District. Wenatchee, Washington.

Mullan J. W., K. R. Williams, G. Rhodus, T. W. Hillman, J. McIntyre. 1992. Production and habitat of salmonids in the mid-Columbia River tributary streams. U.S. Fish and Wildlife Service Monograph I.

Thurow, R.F. 1994. Underwater methods for study of salmonids in the Intermountain West. Gen. Tech. Report INT-GTR-307. USDA, Forest Service, Intermountain Research Station. Ogden, UT.

Wydoski R. S. and R. R. Whitney. 2003. Inland Fishes of Washington. American Fisheries Society University of Washington Press. 


\section{Appendix}

Appendix Table 1. The number of fish observed during day and night snorkel surveys by site surveyed in the Entiat River during 2006 to 2007.

\begin{tabular}{|c|c|c|c|c|c|c|}
\hline Site & Species & $\begin{array}{c}\text { Summer } \\
\text { day }\end{array}$ & $\begin{array}{c}\text { Summer } \\
\text { night } \\
\end{array}$ & $\begin{array}{c}\text { Fall } \\
\text { night }\end{array}$ & $\begin{array}{c}\text { Winter } \\
\text { night }\end{array}$ & $\begin{array}{l}\text { Sub- } \\
\text { total } \\
\end{array}$ \\
\hline \multirow[t]{10}{*}{ City limits main } & Bull trout & - & - & 1 & 0 & 1 \\
\hline & Chinook salmon & - & - & 71 & 10 & 81 \\
\hline & Dace spp. & - & - & 2 & 1 & 3 \\
\hline & Lamprey spp. & - & - & 0 & 1 & 1 \\
\hline & Mountain whitefish & - & - & 8 & 0 & 8 \\
\hline & Rainbow trout & - & - & 26 & 36 & 62 \\
\hline & Sculpin spp. & - & - & 1 & 0 & 1 \\
\hline & Stickleback & - & - & 403 & 0 & 403 \\
\hline & Sucker spp. & - & - & 1 & 2 & 3 \\
\hline & Unknown fish & - & - & 1 & 0 & 1 \\
\hline Sub-total & & - & - & 514 & 50 & 564 \\
\hline \multirow[t]{8}{*}{ City limits side channel } & Chinook salmon & - & - & 62 & 34 & 96 \\
\hline & Dace spp. & - & - & 11 & 1 & 12 \\
\hline & Mountain whitefish & - & - & 0 & 3 & 3 \\
\hline & Rainbow trout & - & - & 14 & 22 & 36 \\
\hline & Redside shiner & - & - & 137 & 1 & 138 \\
\hline & Sculpin spp. & - & - & 1 & 0 & 1 \\
\hline & Stickleback & - & - & 840 & 0 & 840 \\
\hline & Sucker spp. & - & - & 167 & 1 & 168 \\
\hline Sub-total & & - & - & 1,232 & 62 & 1,294 \\
\hline \multirow[t]{8}{*}{ Keystone Canyon } & Chinook salmon & - & - & 138 & 20 & 158 \\
\hline & Dace spp. & - & - & 39 & 6 & 45 \\
\hline & Lamprey spp. & - & - & 1 & 0 & 1 \\
\hline & Mountain whitefish & - & - & 8 & 1 & 9 \\
\hline & Rainbow trout & - & - & 88 & 53 & 141 \\
\hline & Sculpin spp. & - & - & 2 & 1 & 3 \\
\hline & Sucker spp. & - & - & 53 & 1 & 54 \\
\hline & Unknown fish & - & - & 33 & 0 & 33 \\
\hline Sub-total & & - & - & 362 & 82 & 444 \\
\hline \multirow[t]{8}{*}{ Milne } & Chinook salmon & - & - & 56 & 4 & 60 \\
\hline & Dace spp. & - & - & 0 & 1 & 1 \\
\hline & Lamprey spp. & - & - & 0 & 1 & 1 \\
\hline & Mountain whitefish & - & - & 13 & 3 & 16 \\
\hline & Rainbow trout & - & - & 44 & 41 & 85 \\
\hline & Sculpin spp. & - & - & 0 & 2 & 2 \\
\hline & Sucker spp. & - & - & 4 & 5 & 9 \\
\hline & Unknown fish & - & - & 0 & 1 & 1 \\
\hline Sub-total & & - & - & 117 & 58 & 175 \\
\hline
\end{tabular}


Appendix table 1. continued

\begin{tabular}{|c|c|c|c|c|c|c|}
\hline Site & Species & $\begin{array}{c}\text { Summer } \\
\text { day }\end{array}$ & $\begin{array}{c}\text { Summer } \\
\text { night }\end{array}$ & $\begin{array}{c}\text { Fall } \\
\text { night }\end{array}$ & $\begin{array}{l}\text { Winter } \\
\text { night }\end{array}$ & $\begin{array}{l}\text { Sub- } \\
\text { total }\end{array}$ \\
\hline \multirow[t]{10}{*}{ Whitehall cross vane } & Bull trout & 2 & 4 & 3 & 0 & 9 \\
\hline & Chinook salmon & 53 & 118 & 254 & 21 & 446 \\
\hline & Dace spp. & 4 & 45 & 5 & 0 & 54 \\
\hline & $\begin{array}{l}\text { Lamprey spp. } \\
\text { Mountain }\end{array}$ & 0 & 2 & 0 & 0 & 2 \\
\hline & whitefish & 848 & 766 & 3 & 5 & 1,622 \\
\hline & Pikeminnow & 0 & 1 & 0 & 0 & 1 \\
\hline & Rainbow trout & 133 & 106 & 129 & 91 & 459 \\
\hline & Sculpin spp. & 2 & 0 & 1 & 1 & 4 \\
\hline & Sucker spp. & 35 & 14 & 0 & 0 & 49 \\
\hline & Unknown fish & 1,140 & 0 & 25 & 1 & 1,166 \\
\hline Sub-total & & 2,217 & 1,056 & 420 & 119 & 3,812 \\
\hline \multirow[t]{8}{*}{ PUD canal } & Chinook salmon & 265 & 333 & 157 & 14 & 769 \\
\hline & Dace spp. & 2 & 7 & 0 & 0 & 9 \\
\hline & $\begin{array}{l}\text { Lamprey spp. } \\
\text { Mountain }\end{array}$ & 0 & 1 & 0 & 0 & 1 \\
\hline & whitefish & 10 & 44 & 2 & 0 & 56 \\
\hline & Rainbow trout & 52 & 47 & 82 & 55 & 236 \\
\hline & Redside shiner & 1 & 0 & 0 & 0 & 1 \\
\hline & Sucker spp. & 0 & 1 & 2 & 0 & 3 \\
\hline & Unknown fish & 772 & 0 & 0 & 0 & 772 \\
\hline Sub-total & & 1,102 & 433 & 243 & 69 & 1,847 \\
\hline \multicolumn{7}{|l|}{ Dinkelman cross } \\
\hline \multirow[t]{11}{*}{ vane } & Bull trout & 1 & 2 & 3 & 1 & 7 \\
\hline & Chinook salmon & 307 & 200 & 160 & 13 & 680 \\
\hline & Chiselmouth & 0 & 1 & 0 & 0 & 1 \\
\hline & Dace spp. & 9 & 33 & 8 & 1 & 51 \\
\hline & $\begin{array}{l}\text { Lamprey spp. } \\
\text { Mountain }\end{array}$ & 0 & 2 & 0 & 2 & 4 \\
\hline & whitefish & 721 & 688 & 43 & 13 & 1,465 \\
\hline & Pikeminnow & 0 & 1 & 0 & 0 & 1 \\
\hline & Rainbow trout & 294 & 179 & 193 & 92 & 758 \\
\hline & Sculpin spp. & 1 & & 7 & 3 & 11 \\
\hline & Sucker spp. & 54 & 29 & 1 & 0 & 84 \\
\hline & Unknown fish & 2,249 & 820 & 13 & 0 & 3,082 \\
\hline Sub-total & & 3,636 & 1,955 & 428 & 125 & 6,144 \\
\hline
\end{tabular}


Appendix table 1. continued

\begin{tabular}{|c|c|c|c|c|c|c|}
\hline Site & Species & $\begin{array}{c}\text { Summer } \\
\text { day }\end{array}$ & $\begin{array}{c}\text { Summer } \\
\text { night }\end{array}$ & $\begin{array}{c}\text { Fall } \\
\text { night }\end{array}$ & $\begin{array}{c}\text { Winter } \\
\text { night }\end{array}$ & $\begin{array}{l}\text { Sub- } \\
\text { total }\end{array}$ \\
\hline \multirow[t]{9}{*}{ Stanton-Love } & Bull trout & 0 & 0 & 1 & 0 & 1 \\
\hline & Chinook salmon & 75 & 257 & 131 & 13 & 476 \\
\hline & $\begin{array}{l}\text { Dace spp. } \\
\text { Mountain }\end{array}$ & 1 & 152 & 5 & 0 & 158 \\
\hline & whitefish & 385 & 530 & 18 & 5 & 938 \\
\hline & Pikeminnow & 1 & 0 & 0 & 0 & 1 \\
\hline & Rainbow trout & 57 & 114 & 152 & 70 & 393 \\
\hline & Sculpin spp. & 0 & 2 & 3 & 1 & 6 \\
\hline & Sucker spp. & 1 & 7 & 0 & 0 & 8 \\
\hline & Unknown fish & 1,146 & 651 & 27 & 0 & 1,824 \\
\hline Sub-total & & 1,666 & 1,713 & 337 & 89 & 3,805 \\
\hline \multirow[t]{6}{*}{ Hanan-Detwiler ditch } & Chinook salmon & 489 & 473 & 172 & 10 & 1,144 \\
\hline & $\begin{array}{l}\text { Dace spp. } \\
\text { Mountain }\end{array}$ & 6 & 78 & 7 & 0 & 91 \\
\hline & whitefish & 7 & 12 & 3 & 0 & 22 \\
\hline & Rainbow trout & 32 & 116 & 67 & 26 & 241 \\
\hline & Sucker spp. & 0 & 2 & 1 & 0 & 3 \\
\hline & Unknown fish & 223 & 9 & 0 & 0 & 232 \\
\hline Sub-total & & 757 & 690 & 250 & 36 & 1,733 \\
\hline \multirow[t]{13}{*}{ Jon Small barbs } & Bull trout & 2 & 1 & 0 & 0 & 3 \\
\hline & Chinook salmon & 125 & 270 & 276 & 27 & 698 \\
\hline & Chiselmouth & 1 & 0 & 0 & 0 & 1 \\
\hline & Cutthroat trout & 1 & 0 & 0 & 0 & 1 \\
\hline & Dace spp. & 3 & 117 & 4 & 0 & 124 \\
\hline & $\begin{array}{l}\text { Lamprey spp. } \\
\text { Mountain }\end{array}$ & 0 & 1 & 0 & 0 & 1 \\
\hline & whitefish & 250 & 267 & 13 & 10 & 540 \\
\hline & Pikeminnow & 0 & 1 & 0 & 0 & 1 \\
\hline & Rainbow trout & 270 & 200 & 182 & 96 & 748 \\
\hline & Sculpin spp. & 0 & 1 & 6 & 1 & 8 \\
\hline & Sockeye salmon & 0 & 0 & 1 & 0 & 1 \\
\hline & Sucker spp. & 15 & 13 & 8 & 0 & 36 \\
\hline & Unknown fish & 634 & 676 & 5 & 0 & 1,315 \\
\hline Sub-total & & 1,301 & 1,547 & 495 & 134 & 3,477 \\
\hline
\end{tabular}


Appendix table 1. continued

\begin{tabular}{|c|c|c|c|c|c|c|}
\hline Site & Species & $\begin{array}{c}\begin{array}{c}\text { Summer } \\
\text { day }\end{array} \\
\end{array}$ & $\begin{array}{c}\text { Summer } \\
\text { night }\end{array}$ & $\begin{array}{c}\text { Fall } \\
\text { night }\end{array}$ & $\begin{array}{c}\text { Winter } \\
\text { night }\end{array}$ & $\begin{array}{l}\text { Sub- } \\
\text { total }\end{array}$ \\
\hline \multirow[t]{8}{*}{ Knapp-Wham main } & Bull trout & 0 & 0 & 2 & 0 & 2 \\
\hline & Chinook salmon & 348 & 168 & 111 & 3 & 630 \\
\hline & $\begin{array}{l}\text { Dace spp. } \\
\text { Mountain }\end{array}$ & 4 & 128 & 6 & 1 & 139 \\
\hline & whitefish & 327 & 429 & 11 & 4 & 771 \\
\hline & Rainbow trout & 330 & 186 & 213 & 43 & 772 \\
\hline & Sculpin spp. & 2 & 1 & 5 & 0 & 8 \\
\hline & Sucker spp. & 2 & 9 & 0 & 0 & 11 \\
\hline & Unknown fish & 1,406 & 1,409 & 37 & 0 & 2,852 \\
\hline Sub-total & & 2,419 & 2,330 & 385 & 51 & 5,185 \\
\hline \multirow[t]{5}{*}{ Knapp-Wham ditch } & Chinook salmon & 47 & 67 & 7 & 3 & 124 \\
\hline & $\begin{array}{l}\text { Dace spp. } \\
\text { Mountain }\end{array}$ & 3 & 5 & 2 & 0 & 10 \\
\hline & whitefish & 0 & 2 & 0 & 0 & 2 \\
\hline & Rainbow trout & 25 & 9 & 53 & 7 & 94 \\
\hline & Unknown fish & 2 & 0 & 0 & 1 & 3 \\
\hline Sub-total & & 77 & 83 & 62 & 11 & 233 \\
\hline \multirow[t]{9}{*}{ Wilson main } & Chinook salmon & 295 & 250 & 155 & 9 & 709 \\
\hline & Dace spp. & 20 & 102 & 33 & 0 & 155 \\
\hline & $\begin{array}{l}\text { Lamprey spp. } \\
\text { Mountain }\end{array}$ & 0 & 1 & 0 & 1 & 2 \\
\hline & whitefish & 444 & 426 & 65 & 7 & 942 \\
\hline & Pikeminnow & 0 & 2 & 0 & 0 & 2 \\
\hline & Rainbow trout & 193 & 184 & 117 & 45 & 539 \\
\hline & Sculpin spp. & 3 & 3 & 2 & 0 & 8 \\
\hline & Sucker spp. & 2 & 21 & 2 & 0 & 25 \\
\hline & Unknown fish & 1,660 & 1,584 & 141 & 1 & 3,386 \\
\hline Sub-total & & 2,617 & 2,573 & 515 & 63 & 5,768 \\
\hline \multirow[t]{7}{*}{ Wilson side channel } & Chinook salmon & 315 & 596 & 219 & 24 & 1,154 \\
\hline & $\begin{array}{l}\text { Dace spp. } \\
\text { Mountain }\end{array}$ & 0 & 116 & 107 & 0 & 223 \\
\hline & whitefish & 4 & 5 & 3 & 0 & 12 \\
\hline & Rainbow trout & 36 & 122 & 37 & 9 & 204 \\
\hline & Sculpin spp. & 0 & 3 & 1 & 0 & 4 \\
\hline & Sucker spp. & 1 & 9 & 14 & 0 & 24 \\
\hline & Unknown fish & 787 & 60 & 1 & 0 & 848 \\
\hline Sub-total & & 1,143 & 911 & 382 & 33 & 2,469 \\
\hline
\end{tabular}


Appendix table 1. continued

\begin{tabular}{llccccc}
\hline Site & \multicolumn{1}{c}{ Species } & $\begin{array}{c}\text { Summer } \\
\text { day }\end{array}$ & $\begin{array}{c}\text { Summer } \\
\text { night }\end{array}$ & $\begin{array}{c}\text { Fall } \\
\text { night }\end{array}$ & $\begin{array}{c}\text { Winter } \\
\text { night }\end{array}$ & $\begin{array}{c}\text { Sub- } \\
\text { total }\end{array}$ \\
\hline Hatchery & Chinook salmon & 162 & 132 & 69 & 0 & 363 \\
& Cutthroat trout & 1 & 0 & 1 & 0 & 2 \\
& Dace spp. & 6 & 115 & 5 & 0 & 126 \\
& Mountain & & & & & \\
& whitefish & 351 & 324 & 11 & 0 & 686 \\
& Rainbow trout & 252 & 186 & 133 & 50 & 621 \\
& Sculpin spp. & 2 & 2 & 3 & 3 & 10 \\
& Sucker spp. & 0 & 7 & 1 & 0 & 8 \\
Sub-total & Unknown fish & 0 & 1,132 & 0 & 0 & 1,132 \\
Grand Total & & 774 & 1,898 & 223 & 53 & 2,948 \\
& & & & & & \\
& & 17,709 & 15,189 & 5,965 & 1,035 & 39,898 \\
\hline
\end{tabular}

